Pirineos, 157: 57 a 63, JACA; 2002

\title{
DIET COMPOSITION OF ROE DEER (CAPREOLUS CAPREOLUS) IN THE NATURAL PARK OF THE GARROTXA VOLCANIC ZONE (CATALONIA, SPAIN)
}

\author{
J. BARTOLOME ${ }^{1}$, C. ROSELL $L^{2} \&$ E. BASSOLS ${ }^{3}$ \\ ${ }^{3}$ Departament de Ciència Animal i dels Aliments. Lniversitat Autonoma de Barcelona. 08193 Bellaterra \\ (Spain). E-mail: jordibartolomeQuab.es \\ ${ }^{2}$ Mirnuartia, Estudis Ambientals, Passatge Domènedh, 3, 1r, E-08470 Sant Celoni (Spain). \\ E-mail: crosell@minuartia,com \\ ${ }^{3}$ Parc Natural de la Zona Volcónica de la Garrotxa. Casal dels Volcans. Av. de Santa Coloma, s/n. \\ 17800 Olot (Spain). E-mail: webassol@correu.gercat.es
}

\begin{abstract}
The present work owthes the results of a study on the food consumed by roe deer carried out in the Nafural Park of the Garrotxa Volcanic Zone, where 49 roe deer were reintroduced from 1995 to 1998 . This is a protected aren of about 12,000 ha, in which onk and beech forsts predominate. Faect analysis uns chosen as the most appropriate method for sampling diet composition despite the scarcity of frecol samples encountered from 1998 io 2001 ( $n=30$ ). A total of 7,500 epidermal frogments were identified from these samples. Results showed that ivy (Hedera helix) and bramble (Rubus sp.) formed the bulk of the diet ( $23 \%$ and $21 \%$, respectionly). Woody species also formed an important part, reaching $33 \%$ of total fragments. herbs and grasses were only notable in the spring-simmer periad. Some major opgetation components such as beech (Fagus sylvatica) toere mely consumed by deer.

RESLIME,- Voici le resulkat d'ure Étude sur lailinentation du chevreuil dans it" Parc Naturel de la Zone Volcanique de la Grrrotxa, où 49 individus furent introduits entre 1995 et 1998. II s'agit d'un espace protëgé de $12000 \mathrm{ha}$ environ, dominé par les forêts de chênes ef de helres. Malgré le nombre très bas dexcrénents rencoutrés entre 1998 et 2001 ( $n=30$ ), leur analyse nous a paru lif meilleure methode pour tester in composition de lalimentation, A parlir de ces echantillons, nous avons identifis 7500 fragments d" Epidermte. Les résultats nous montrent gue le lierre (Hedera helixl ct in ronce (Rubus sp.) sont ['alimentation principale (23 et $21 \%$ respectionement). Toutefois, les especes ligneuses sont également à considérer, puistiu'elles forment $33 \%$ des fragments totaux. Les herbes et les graminées s'averent importantes ou cours du printemps-té. Il est à noter que les principnux composants de la zegetation thl the hite (Fagus sylvatica) étaient très marment consontmés.
\end{abstract}


RESUMEN - Se exponen los resultados de un estudio de la alimentncion del corzo ilezado a cabo en el Parque Natural de la Zona Volcanica de la Garrotxa, donde 49 corzos fueron reintroducidos desde 1995 hasta 1998 . Ëste área protegida comprende unas 12.000 ha con predominio de bosques de roble y hrya. El anailisis de heces fue considerado como el método mís apropiato para deteminor la composición de la dieta, a pesar de la escrez de muestras fecales halladas desde 1998 a 2001 ( $n=30$ ). A partir de dichas smuestras fueron identificados un tolal de 7.500 fragmentos epidémicos. Los resultados muestran que la hiedra (Hedera hetix) y la zarza (Rubus sp.) forman el grueso de la dieta $(23 \%$ y $21 \%$, respectioamente). Las especies lefiosas forman también una parte importante, alcanzando el $33 \%$ del total de los fragmentos ipidérnicos. Las herbicuns solo fueron importantes ent el periado primatera-zeranto. Algthos contponentes mayoritarios de ha vegetación, como el haya (Fagus sylvatica), fueron raramente consumidos.

Key-words: Microhistological analysis, faecal analysis, diet, ivy, bramble, oak, beech.

\section{Introduction}

Between 1995 and 1998 , a total of 49 roe deer were reintroduced into the Natural Park of the Garrotxa Volcanic Zone (NPGV), in the NE of Spain. The monitoring plan of this population includes spatial distribution, demographic evolution, parasite control and diet selection (MINUARTIA, 1994; ROSELL, 2001). All of these parameters are difficult to estimate in forested areas (VINCENT ef al., 1991). Management of roe deer is controversial because farmers and foresters are concerned the roe deer's population effect on field crops and natural tree regeneration.

The aim of this work was the determination of the natural diet of roe deer in the NPGV.

\section{Material and Methods}

The study area comprises the whole of the Natural Park. A mosaic of forests dominates the landscape in this area: evergreen oak (Quercus ilex), other oak species (mainly Quercus humilis) and beech (Fagus sylvatica). Agricultural lands that cover the flat areas and common field crops grow alfalfa (Medicago sativa), rye grass (Lolium multiforum) and corn (Zea mays).

Roe deer diets were estimated by determining the species composition of epidermal fragments in the faeces, in accordance with the procedures of the microhistological analysis employed by different authors (CROCKER, 1959; STEWART, 1967; GARCIA-GONZÁLEZ, 1984; BARTOLOMÉ et al, 1995).

The NPGV Guard Service collected faecal samples in the field between 1998 and 2001. Different pellet groups were considered as arising from diffe- 
rent individuals. Despite sampling being carried out once per month, only a total of 30 samples were collected during this period. Fortunately, samples ranged over the whole annual cycle.

Two-way indicator species analysis (TWINSPAN) applied to the sampledata set was employed in classifying diet types (HILL \& GAUCHE, 1980).

\section{Results and Discussion}

A total of 7,500 epidermal fragments were identified in faecal samples and these were grouped in 56 different taxa. Figure 1 shows the mean annual diet for roe deer. The most important component in the diet were ivy (Hedera helix) and bramble (Rubus sp.) at $23 \%$ and $21 \%$ respectively, followed by woody species (mainly Quercus sp.), which account for 33\%. Forbs represented $12 \%$, and graminoids were the smallest fraction, at only $8 \%$. These global results correspond with the finding of other authors who had studied the food preferences of roe deer in woodland areas (JACKSON, 1980; HOSEY, 1981; DEGREZ \& LIBOIS, 1991; TIXIER et al, 1997), even when other ungulate species are present (HEROLDOVA, 1996).

The main taxa and maximum values recorded in faecal samples are shown in Table 1. Ivy, bramble and evergreen oak were present in almost all samples. Ivy and bramble represented more than half of the diet in any sample, with evergreen oak at almost $40 \%$.

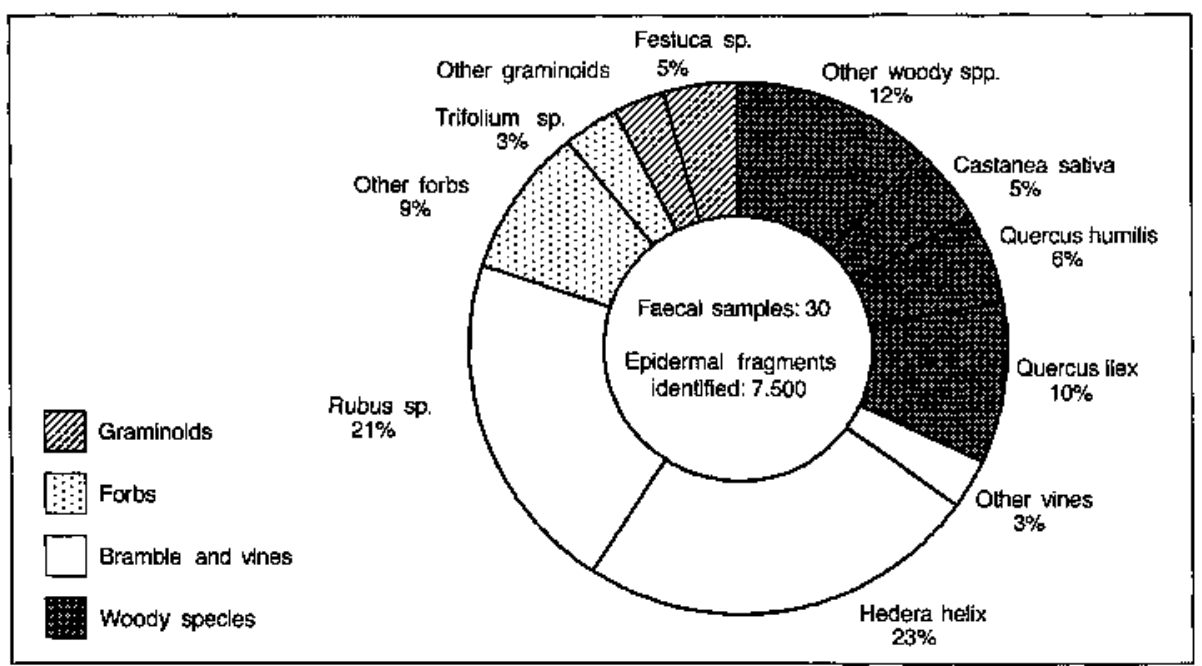

Figure 1. Mean annual diet of roe deer in the Natural Park of the Garrotxa Volcanic Zone. 
PIRTNEOS 157

Table 1. Main taxa recorded in fecal samples of toe deer $(\mathrm{n}=30)$ in the Natural Park of the Garrotxa Volcanic Zone.

\begin{tabular}{|lcc|}
\hline & $\begin{array}{c}\text { Number of samples } \\
\text { with the taxon }\end{array}$ & $\begin{array}{c}\text { \% maximum } \\
\text { recorded }\end{array}$ \\
\hline Rubus sp. & 30 & 53,6 \\
Hedera helix & 27 & 55,6 \\
Quercus ilex & 29 & 38,8 \\
Quercus humilis & 21 & 35,2 \\
Citysus scoparius & 23 & 33,2 \\
Castanea sativa & 14 & 28,4 \\
Festuca sp. & 13 & 30,8 \\
Trifolium sp. & 16 & 25,6 \\
Pferidophyta & 11 & 8,0 \\
Verbascum sp. & 6 & 47,6 \\
Bryophyta & 5 & 21,2 \\
Medicago sativa (cultivated) & 2 & 24,8 \\
Lolium multifrorum (cultivated) & 2 & 2,4 \\
Zea mays (cultivated) & 2 & 0,4 \\
Buxus sempervirens & 4 & 3,6 \\
\hline Total taxa=56 & & \\
\hline
\end{tabular}

Besides of ivy, some other toxic species were also well reptesented in the diet. Pteridophyta (probably Pteridium aquilinum) appeared in 11 samples; Verbascum sp. in 6, with this reaching $48 \%$ of the diet in one sample, and Buxus sempervirens in 4 .

Cultivated species were highly occasional: they appeared in only 2 samples of each species. Alfalfa was the only cultivated species that represented an important percentage of the diet ( $25 \%$ in one sample).

Figure 2 shows the dendrogram obtained by TWINSPAN analysis of the samples. The first division (level 1) separated the more herbaceous diets $(n=5)$ from the rest $(n=25)$. A 'herbaceous diet' means a clear dominance of forbs and graminoids in the sample. All of these were collected in the spring-summer period. The second division (level 2) distinguished two other subgroups in the herbaceous group, one with highly herbaceous diets $(n=3)$ and the other with mixed diets $(n=2)$. A 'mixed diet' means a similar percentage of woody and herbaceous species.

On the other hand, level 2 grouped all the winter samples ( $n=11$ ), which were dominated by woody diets. A 'woody diet' means a clearly higher percentage of woody species in the sample. The remaining samples $(n=14)$ were divided at level 3 into two other groups. One of these grouped 3 mixed-diet samples collected in spring-summer period. The other group ( $\mathrm{n}=11)$ included the remaining woody diet samples; at level 4 , these were separated into a group of 6 samples collected in the autumn period, and another of 5 samples collected in the spring-summer period. 


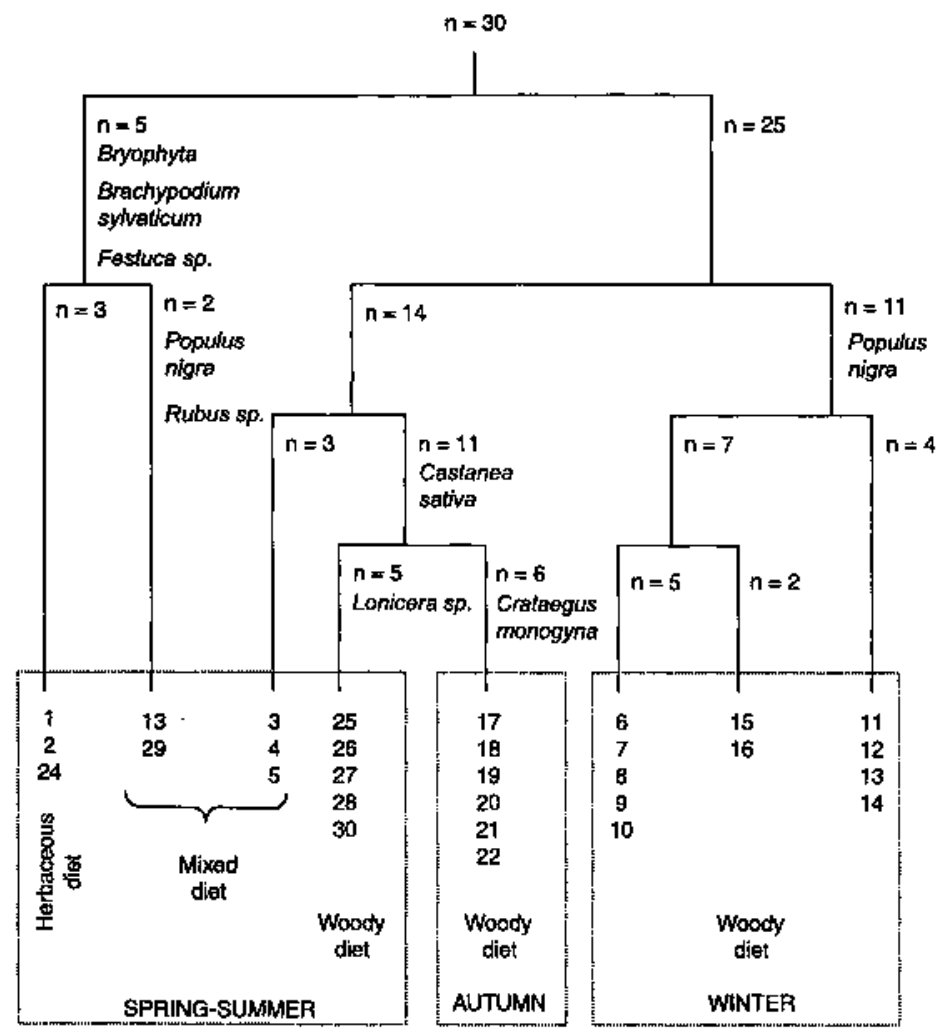

Figure 2. Results of the TWINSPAN analysis expressed as a dendrogram showing hierachical subdivisions of the samples $x$ species data set to level 4 . Indicator species are listed next to the branches.

To summarise, roe deer diets in the autumn and winter periods were dominated by woody species, and can be catalogued only as woody diets. However, in the spring and summer time, the proportion of woody and herbaceous species was highly variable between samples; the diets in this period can be defined as herbaceous, mixed or woody.

\section{Conclusions}

Ivy (Hedera helix) and bramble (Rubus sp.) formed the bulk of the annual roe deer diet (23\% and $21 \%$, respectively) in the Natural Park of the Garrotxa Volcanic Zone. 
In the spring-summer period, it is possible to distinguish between a woody diet, a mixed diet or a herbaceous diet. Throughout the rest of the year, ligneous species were the major dietary components, and only a woody diet was obtained.

In this study, the roe deer diet corresponded to that of a concentrated selector ungulate, according to Hofmann (1989). Consequently, in addition to the more common species (bramble, ivy and oak), roe deer occasionally consumed certain other species, such as Verbascum sp., in high proportion.

According to these results, agricultural plants are consumed only occasionally and the main forest trees present in the area do not represent an important part in roe deer's diet. It is therefore suggested that consumption by this ungulate does not cause any significant problem to agricultural or forestry activities.

Acknowledgements. We would like to thank the Zona Volcànica de la Garrotxa Natural Park (Departament de Medi Ambient de la Generalitat de Catalunya) for financial assistance and to express our gratitude to their staff for field collaboration.

Thanks also go to the technicians of the consultant company, MINUARTIA, Estudis Ambientals, and also to Dr. Josefina Plaixats of the Animal and Food Science Department (Unizersitat Autònoma de Barcelona).

\section{References}

BARTOLOMÉ, J; FRANCH, J.; GUTMAN, M. \& SELIGMAN, N. G. (1995). Physical factors that influence fecal analysis stimates of herbivore diets. J. Range Manage, 48: 267-270.

CROCKER, B. H. (1959). A method of stimating the botanical composition of the diet of sheep. New Zealand J. Agr. Res., 2: 72-85.

DEGREZ, I. \& LIBOIS, R. B. (1991). Seasonal variations of the diet of the roe deer (Capreolus capreolus) in southern Belgium. Cath. Ethol. 11, $\mathrm{n}^{\circ}{ }^{\circ} 1: 17-30$.

GARCfA-GONZÁLEZ, R. (1984). L'emploi des epidermes végétaux dans la détermination du régime alimentaire de l'Isard dans les Pyrénées occidentales. Ecologie des milieux montagnards et de haute altitude. Documents d'Écologie pyrénéenne, III-IV: 307-313.

HILL, M. O. \& GAUCH, H. G. (1980). Detrended correspondence analysis: an improved ordination technique. Vegetatio, 42: 47-58.

HEROLDOVA, M. (1996). Dietary overlap of three ungulate species in the Palava biosphere Reserve. Forest Ecology and Management, 88: 139-142. 
HOFMANN, R. R. (1989). Evolutionary step of ecophysiological adaptation and diversification of ruminants: a comparative view of their digestive system. Oecologia, 78: 443-457.

HOSEY, G. R. (1981). Annual foods of the Roe deer (Capreolus capreolus) in the south of England. Journal of Zoology, 194: 276-278.

JACKSON, J. (1980). The annual diet of the Roe deer (Capreolus capreolus) in the New Forest, Hampshire, as determined by rumen content analysis. J. Zool. Lond., 192: 71-83.

MINUARTIA, ESTUDIS AMBIENTALS (1994). Projecte de reintroducció del cabirol (Capreolus capreolus) al Parc Natural de la Zona Volcànica de la Garrotxa. Departament de Medi Ambient. Generalitat de Catalunya (unpublished).

ROSELL, C. (2001). Los ungulados y los ecosistemas forestales: los ejemplos del jabalí y el corzo. In CAMPRODON, J. \& PLANA, E. (Eds.). Conservación de la Biodiversidad y gestión forestal. Su aplicación a la fauna vertebrada. Universitat de Barcelona: 377-396.

STEWART, D. R. M. (1967). Analysis of plant epidermis in faeces, a technique for studying the food preferences of grazing herbivores. J. Appl. Ecol, 4: 83-111.

TIXIER, H.; DUNCAN, P.; SCEHOVIC, J.; YANI, A,; GLEIZES, M. \& LILA, M. (1997). Food selection by European roe deer (Capreolus capreolus): Effects of plant chemistry and consequences for the nutritional value of their diets. Journal of Zoology, 242: 229-245.

VINCENT, J. P; GAILLARD, J. M. \& BIDEAU, E. (1991). Kilometric index as a biological indicator for monitoring forest roe deer populations. Acta Theriol., 36: 315-328. 